Article

\title{
FOSSIL CAPITALISM, CLIMATE CAPITALISM, ENERGY DEMOCRACY: THE STRUGGLE FOR HEGEMONY IN AN ERA OF CLIMATE CRISIS
}

\author{
WILLIAM K. CARROLL \\ Sociology Department, University of Victoria
}

\begin{abstract}
With the highest per capita carbon emissions among the G20, Canada presents the interesting case of a climate laggard and, in some respects, a first-world petro-state. In these circumstances, a regime of obstruction, with a distinctive political-economic architecture, has taken shape. This regime is constituted through modalities of power that protect revenue streams issuing from carbon extraction, processing and transport while bolstering popular support for an accumulation strategy in which fossil capital figures as a leading fraction. It incorporates a panoply of hegemonic practices at different scales, reaching into civil and political society, and into Indigenous communities whose land claims and worldviews challenge state mandated property rights. This article first highlights findings from a six-year collaborative investigation of the modalities through which fossil capital's economic and political-cultural power is exercised at different scales, then outlines how the passive-revolutionary project of 'climate capitalism' is taking shape in the Canadian context as a response to climate crisis, and finally considers how a project of energy democracy, might hold the potential to catalyze the formation of an alternative historical bloc, opening onto eco-socialism.
\end{abstract}

\section{Introduction}

As the $21^{\text {st }}$ Century's second decade draws to a close, the increasingly severe symptoms of climate change comprise a pivot and perhaps a turning point in the struggle for hegemony, globally and within national formations. 'This Changes Everything,' wrote Naomi Klein (2014) in presenting capitalism as the incontrovertible enemy of the climate. Yet as Klein herself recognized, the ascent of transnational neoliberalism has complicated prospects for moving beyond marketdriven extractivism and endless growth. Indeed, Wainwright and Mann (2018) hold that the most likely future scenario is that of Climate Leviathan, a more authoritarian capitalism governed by strong states that manage the climate through technologies and market mechanisms that reinforce

${ }^{1}$ This paper is part of the Corporate Mapping Project (CMP), a research and public engagement initiative investigating the power of the fossil fuel industry. The CMP is jointly led by the University of Victoria, Canadian Centre for Policy Alternatives and the Parkland Institute. This research was supported by the Social Science and Humanities Research Council of Canada (SSHRC). An earlier version of this article was presented as an invited address to 'Antonio Gramsci: a legacy for the future,' Simon Fraser University, October 21, 2018.

Socialist Studies / Études socialistes:

The Journal of the Society for Socialist Studies / Revue de la Société d'études socialistes.

www.socialiststudies.com. ISSN 1918-2821 
capitalist class power and North-South inequities. Fossil capitalism's organic crisis is twofold, both civilizational and ecological, and global in scale. Yet despite the emergence of a transnational capitalist class and of global governance institutions attuned to crisis management, national formations, and the economic, political and cultural forces centred within them, continue to hold considerable sway (Carroll 2018). Within each national theater of contention, capital and its allies strive to maintain a competitive economy, and to win the continuing loyalty of broad swathes of the general public and strategically targeted subaltern groups.

With the highest per capital carbon emissions among the G20 states (Rabson 2018), Canada presents the interesting case of a climate laggard and, in some respects, a first-world petro-state (Nikiforuk 2010). Canada holds the world's third largest reserves of oil, but $97.4 \%$ of these are 'lowquality oil sands that are energy- and emissions-intensive to extract and costly to refine' (Hughes 2018: 164). Although jobs directly in the fossil-capital sector account for a tiny fraction of the national workforce, and although state revenues from that sector have plunged in recent years to negligible levels (ibid), political and corporate leadership is solidly behind a slightly modified 'business-as-usual', with carbon extraction continuing to increase (even as other measures partly mitigate ever-growing emissions). Thirteen years after Prime Minister Stephen Harper declared Canada an 'energy superpower', a bloated oil and gas sector centred upon the tar sands is integral to 'the decisive nucleus of economic activity' (Gramsci 1971: 161) that hegemony protects.

In these circumstances, a regime of obstruction, with a distinctive political-economic architecture, has taken shape. Building on hegemonic relations installed during successive eras of organized capitalism and neoliberal capitalism, this regime is constituted through modalities of power that protect revenue streams issuing from carbon extraction, processing and transport while bolstering popular support for an accumulation strategy in which fossil capital figures as a leading fraction. The regime incorporates a panoply of hegemonic practices at different scales, reaching into civil and political society, and into Indigenous communities whose land claims and worldviews challenge state mandated property rights.

Yet the visibly deepening climate crisis challenges fossil capitalism while the rise of 'climate capitalism' as an alternative accumulation strategy (Sapinski 2015, 2016) opens space for a passive revolution that would protect capital's economic nucleus while (conceivably) avoiding catastrophic climate change. The organic crisis also opens space for an alternative from the left, namely 'energy democracy', which I conceptualize as a bundle of non-reformist reforms (Gorz 1967) that may hold out the possibility of an anti-passive revolution pointing toward an ecosocialist resolution of the crisis.

This article draws upon findings from a six-year collaborative investigation, centred on the case of Canada. Our project combines social science inquiry with popular education and democratic advocacy, in an ongoing program of public sociology and action research (Carroll and Daub 2018). ${ }^{2}$ I first highlight some of our findings on the modalities through which fossil capital's economic and political-cultural power is exercised at different scales, then outline how the passive-

\footnotetext{
${ }^{2}$ For details on the Corporate Mapping Project go to https://www.corporatemapping.ca/.
} 
revolutionary project of 'climate capitalism' is taking shape in the Canadian context as a response to climate crisis, and finally consider how a project of energy democracy, currently on the margins of civil and political society, might hold the potential to catalyze the formation of an alternative historical bloc, opening onto eco-socialism.

\section{Modalities of Corporate Power}

In mapping the carbon-extractive sector's organization, its political-cultural reach and also popular resistance to its power, our project offers a relational analysis of hegemony, attuned to political-economic as well as discursive structures and practices. At the centre of the analysis is the idea that corporate power is wielded through a number of distinct modalities.

A Gramscian perspective invites us to distinguish two dialectically constituted faces of contemporary corporate power - the economic and the political-cultural. Following Urry (1981), Figure 1 schematizes these as a distinctive architecture comprised of three overlapping fields: state, civil society and economy. Although these are differentiated, they are not separate. Gramsci observed that 'the state intervenes at every moment of economic life, which is a continuous web of transfers of property' (2007: 10). In his prison notebooks 'there is a generative understanding of "civil society" not as a separate sphere in opposition to the "state" but as an element in dialectical unity with "political society"' (Bieler and Morton 2018: 14).

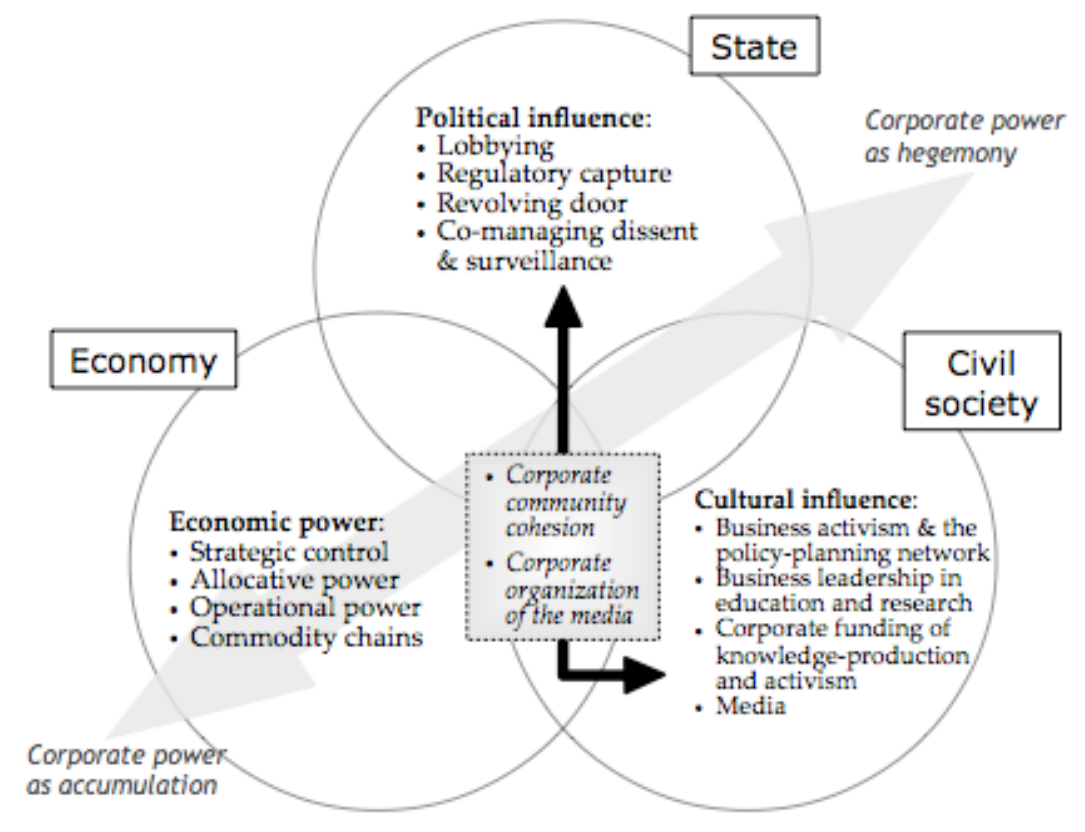

Figure 1. Modalities of corporate power (from Carroll and Sapinski 2018:101) 
Corporate power's economic face is coterminous with the entire process of capital accumulation, from extraction, manufacturing and transport through marketing and finance. Economic power is inscribed in control of the labour process, in the wealth that capital appropriates, as profit, from labour and the rest of nature, and in the economic dependence of workers, communities and states on corporate investments, to generate jobs and revenue.

There are several distinct modalities of economic power. Operational power is the power of management, flowing through a chain of command, in the appropriation of surplus labour. But it is also wielded along commodity chains, from resource extraction, through processes of transport, processing, to manufacturing and distribution. In Canada, bitumen represents four-fifth of extractable oil (Hughes 2018), and five large companies control most of the action, with two additional firms dominating the continental pipeline infrastructure (Hussey, Pineault, Jackson and Cake 2020). Strategic power, the power to set business strategies, involves control of the corporation itself, often by owning the largest bloc of shares. Our mapping of share ownership of leading Canada-based fossil-capital corporations reveals a confluence of Canadian capitalist ownership - via families and financial institutions - and foreign ownership via transnational corporations and asset managers. These ownership relations are arrayed in a network of many weak ties (smaller institutional holdings) and a few dozen large holdings that confer strategic control upon their corporate or personal owners. The concentration of fossil capital and of its ownership/control represents a massive centralization of economic power in the hands of private investors accountable only to themselves (Carroll and Huijzer 2018). Finally, allocative power stems from the control of credit, the money-capital on which large corporations depend. This power, which accrues to financial institutions of all sorts (banks, life insurers, asset managers, hedge funds etc.), is crucial in expanding or retooling operations, launching takeover bids or coping with cash squeezes during crises (Carroll and Sapinski 2018). Canada's financial sector is dominated by five big banks, each of which enables the accumulation of fossil capital and appropriates a portion of the surplus, through loans and share ownership, sometimes accompanied by interlocking directorates (ibid). A recent study by the Rainforest Action Network identified all five of Canada's big banks as international leaders in the funding of fossil capital. ${ }^{3}$ These economic modalities are integrated within a complex circuitry in which capital metamorphoses across the productive, commercial and financial forms initially identified by Marx (1967a).

Figure 1 also depicts the hegemonic face of corporate power, as it extends into the political and cultural fields. Hegemonic power refers to how consent is secured, organized and maintained, from the visceral level of everyday life up to the top tiers of state and inter-governmental institutions. Within political and civil society corporate power is exercised by capital's organic intellectuals: including corporate capitalists as 'business leaders'. As Giuseppe Vacca (1982) has noted, such intellectuals are 'organic' in a double sense: they are 'organizers' of an advanced capitalist way of life, and their intellectual work is functionally (organically) predicated on the dominance of capital in human affairs. Most organic intellectuals are not capitalists but well-placed

\footnotetext{
${ }^{3}$ See https://www.ran.org/banking on climate change
} 
and highly skilled professionals whose agency legitimates and facilitates the corporate system, through public relations and media, policy formation, lobbying, higher education, accounting and corporate law, etc. (Carroll and Shaw 2001).

Such experts can also be found on the directorates of leading corporations, where they function in an advisory capacity, integrating the corporate elite by serving on multiple boards. Indeed, a dense network of interlocking directorates among Canada's leading fossil-capital companies pulls together capitalists and organic intellectuals, as a cohesive elite within the wider Canadian corporate community (and the even wider transnational capitalist class, Carroll 2010). Within this elite, power is centralized, as top capitalists and their advisors interact frequently, maintaining a sense of solidarity and common purpose even as they compete over the division of spoils appropriated from labour and nature. The corporate community's cohesiveness is an important modality of hegemony, as it enables corporate capital to reach a consensus on long-term goals and vision, and on that basis, to speak politically with a single voice, and lead.

Network-analytic findings from our project make this clear. The dense core of the fossilcapital elite is centred in Calgary, host to most Canadian fossil-capital firms, many of which share directors, creating a highly integrated local network. The Calgary-based core, in turn, is part of a regionalized national network, as fossil companies share directors with financial institutions based mainly in Toronto, and with other major Canadian corporations. The Canadian national network is embedded in a transnational elite network that includes major corporations based in Europe, Asia and the USA (Carroll 2017).

Complementing elite integration is the reach of corporate power into the public sphere, shaping the institutions, agendas, policies, discourses and values that add up to an entire way of life. Corporate reach is a many-splendored thing. Vis-à-vis civil society, it includes, among other hegemonic practices:

- $\quad$ business leadership exercised by corporate elites as they govern business councils, industry groups, policy-planning organizations, and institutions of high education and research (Carroll, Graham, Lang, McCartney and Yunker 2018),

- $\quad$ selective allocation of funds to business-friendly think tanks, advocacy groups, foundations, political parties etc.,

- $\quad$ public-relations and corporate social responsibility initiatives,

- $\quad$ the framing of news and other media content to privilege business interests (who as advertisers selectively fund that content; Hackett and Adams 2018), and

- the corporate organization of communications media, whose goal of profit maximization trumps the public interest.

Corporate funding of civil-society organizations is itself an expression of allocative power reaching into and colonizing the public sphere. Funds accumulated as capital are selectively directed, often through private foundations, to initiatives aligned with corporate business, including policy-planning groups, political parties, lobbies and industry groups, universities and research centres, community organizations and petro-turf advocacy groups such as Canada's 
Energy Citizens, which is a creature of the Canadian Association of Petroleum Producers (CAPP) (Carroll, Graham, Lang, McCartney and Yunker 2018).

Corporate power reaches into the state through a range of hegemonic practices. These include:

- $\quad$ intensive and sustained lobbying. According to Canada's Federal Lobbying Registry, in 2017 alone, CAPP logged 162 lobbying events with the federal government, averaging more than three meetings each week with top officials.

- $\quad$ regulatory capture. Canada's National Energy Board (NEB) rubber-stamped industry proposals for years, leading an investigative panel to observe in 2017 that 'Canadians have serious concerns that the NEB has been "captured" by the oil and gas industry, with many Board members who come from the industry that the NEB regulates, and who - at the very least appear to - have an innate bias toward that industry' (McCarthy 2017; cf. Daub, Ejeckam, Graham and Yunker 2020).

- $\quad$ revolving doors, through which capital's business leaders and organic intellectuals become political leaders and vice versa. ${ }^{4}$

A final aspect of corporate reach into political society aligns corporations with the repressive arm of the state, as co-managers of dissent and surveillance. When hegemony fails when dissent becomes well organized and potentially effective - the state turns to more repressive means of social control. Vis-à-vis fossil capital, this began to happen under the Harper regime (2006-2015), as coalitions of Indigenous, environmental and social-justice activists rose up in opposition to proposed pipelines such as Northern Gateway and Keystone XL. The state response was to mobilize its security agencies in partnership with top fossil-fuel corporations, to protect 'strategic infrastructure' (Crosby and Monaghan 2018). Although the Trudeau government softened the legal language in 2017, it continues to target 'interference with critical infrastructure' as a threat to national security and to allow authorities to detain protestors by 'preventative arrest', within a framework of 'partnership' between state and corporate owners (Rowley 2017). This last power modality reminds us that although hegemony is ethico-political, its persuasive efforts are armored with coercion.

\footnotetext{
${ }^{4}$ For instance, Preston Manning, son of Ernest Manning, the right-wing populist premier of Alberta from 1943 to 1968, served as management consultant to fossil capital and CEO of a mid-sized property-development company before founding the Alberta-centred Reform Party in 1987 (appointing Stephen Harper as Policy Chief). Both Manning and Harper were elected to parliament in 1993, and Manning became Opposition Leader in 1997. After his retirement from politics in 2002, he founded the Manning Centre for Building Democracy, a vehicle for the 'Gramscian right' (George 1997) whose project is 'to support Canada's conservative movement by networking best practices \& ideas pertaining to individual responsibility and a more robust civil society.' See https://www.manningcentre.ca. The Reform Party's successor, the Canadian Alliance Party, effectively took over Canada's Progressive Conservative Party in 2004, under Harper's leadership. For his part, after serving as Canada's Prime Minister (2006-2015), Harper founded a consultancy, Harper \& Associates, joined the advisory board of Azimuth Capital Management, and in February 2018 was elected President of the International Democratic Union, an umbrella organization for right-wing parties that include Hungary's Fidesz, India's BJP, Israel's Likud and the US's Republicans - all currently in power. See https://www.idu.org/.
} 
These various modalities can be placed within a wider framework that recognizes that power implies resistance (Barbalet 1985). Resistance to (fossil) capital takes many forms, e.g.:

- $\quad$ shop-floor struggles of workers against the lash of management,

- $\quad$ protests, boycotts and blockades at key junctures along commodity chains,

- $\quad$ movements challenging corporate power on the basis of climate justice and Indigenous claims,

- $\quad$ shareholder activism and divestment campaigns, engaging the power of investors,

- calls for the private allocative power of finance to be brought under public control,

- critiques of the concentration of power within old boys' clubs and corporate elites,

- $\quad$ demands to remove big money from politics and to end the institutional corruption that infects practices of business lobbying,

- court challenges to capitalist projects, brought by environmental and Indigenous organizations,

- media activism pushing to democratize public communication while fostering community-based media,

- counter-hegemonic projects to transform our way of life - as in the 2015 Leap Manifesto, which proposed to shift from fossil capitalism to energy democracy. ${ }^{5}$

Although this article focuses on the regime of obstruction, issues of resistance (and even transformation) are never far below the surface, and in the final section I will explore the prospects for energy democracy as an alternative to fossil capitalism.

\section{Accumulation strategies, hegemonic projects, historical blocs}

In a Gramscian perspective, power grounded in practices of capital accumulation and power resident in political and cultural practices are dialectically related. To the extent that they cohere into a way of life, whether regnant or aspirational, they form the institutional and ideological foundations of an historical bloc. For Gramsci,

...the historical bloc reflects 'the necessary reciprocity between structure and superstructure' ([Gramsci] 1971: 366). This reciprocity is realized through specific intellectual, moral and political practices. These translate narrow sectoral, professional, or local (in his terms, 'economic-corporate') interests into broader 'ethico-political' ones. Thus the ethico-political not only helps to co-constitute economic structures but also provides them with their rationale and legitimacy (Sum and Jessop 2013: 199).

Inspired by French Regulation Theory (Aglietta 1979), Jessop (1983) has helped specify the core components of historical blocs through the couplet, 'accumulation strategies' and 'hegemonic

${ }^{5}$ http://leapmanifesto.org/en/the-leap-manifesto/. 
project'. Across the Global North during the post-war boom era, the reciprocally-reinforcing complex of fordist consumer capitalism (accumulation strategy) and Keynesian Welfare State (hegemonic project) came to comprise an expansive historical bloc that included organized labour. This bloc began to unravel in the stagflation of the 1970s. It gave way to a more transnationalized neoliberal paradigm, catalyzed by Thatcherism and Reaganism. Financial capital came to play the leading role, in an accumulation strategy of 'supply-side', trickle-down economics and in the 'market-driven politics' (Leys 2001) of a deregulatory regime offering jobs and lower taxes as material concessions to the atomized worker-consumer, on the condition that obstacles to investment (including no-longer-affordable state programs) be removed (Carroll 2003).

Under neoliberalism a different historical bloc was assembled in the Global North, favouring financial capital and the asset-owning middle class (Van der Pijl and Yurchenko 2014), expelling organized labour, and with it, the politics of class compromise. Neoliberalism stoked accumulation, but it narrowed the hegemonic bloc, shrinking the middle class, intensifying class inequities, and ultimately creating a bubble of over-accumulated fictitious capital (Durand 2017), which burst in the autumn of 2008. Yet with the failure of any alternative to neoliberal capitalism to gain popular traction, neoliberalism has limped along while right-wing populism gains ground, with authoritarian and neo-fascist leadership now installed in Hungary, the Philippines, Brazil, the US and elsewhere - a development that ultimately raises challenges for transnational neoliberalism's commitment to open borders and the rule of law.

This narrative of shifting accumulation strategies and hegemonic projects can be enhanced by bringing political ecology into the picture. Four historical periods can be distinguished:

1. Fossil capital has been at the core of capital accumulation since the early-to-mid decades of the $19^{\text {th }} \mathrm{C}$, and capitalism could not have become globally dominant without resort, at mass-production scale, to the power of buried sunshine (Malm 2016).

2. In the close integration of financial and industrial capital that marked the formation of corporate capitalism, fossil capital held a central place, as it did in the 'carbon democracy' (Mitchell 2011) through which the western working class gained concessions as the Middle East was colonized for its oil.

3. Post-war consumer capitalism brought suburbanization and automobility, as fossil-fueled articles of consumption reshaped the lifeworlds of Northern worker-consumers while carbon pollution accelerated. This combination of accumulation and hegemony set the table for neoliberalism by fostering entrepreneurial subjects interested mainly in their own retained earnings (Huber 2013). Neoliberal globalization since the 1980s has intensified both the penetration of fossil capital into lifeworlds, worldwide, and the volume of carbon emitted.

4. In our current era, fossil-fueled consumer capitalism continues to be paradigmatic yet, spurred by the deepening climate crisis, alternatives have been taking shape, portending change in the hegemonic historical bloc. 


\section{Fossil capital within the hegemonic bloc}

Gramscian thinking foregrounds how consent is organized on many scales - from households and families up to 'the historic blocs underpinning particular states [which] become connected through the mutual interests and ideological perspectives of social classes in different countries - portending 'an incipient world society' (Cox 1987:7). In this perspective, globalization is seen not as an abstract process but as 'the complex and emergent product of various practices and processes operating on many scales' (Jessop, 2002:113). Drawing on research from our collaborative project and related endeavors, we can unpack how the hegemony of fossil capital works within a multi-scalar regime of obstruction, extending from the everyday to the global. Table 1 offers some key instances (discussed below), but should not be seen as anything like a complete inventory.

Table 1: The regime of obstruction at different scales

\begin{tabular}{|l|l|}
\hline Scale & Key instances \\
\hline Everyday life & $\begin{array}{l}\text { Fossil-fueled consumer capitalism as a way of life: the } \\
\text { privatized geography of automobility and suburbanization }\end{array}$ \\
\hline Local community & $\begin{array}{l}\text { Civic privatism/boosterism and hegemonic community } \\
\text { economic identity: “The oil industry is us"; Indigenous } \\
\text { ambivalence }\end{array}$ \\
\hline Institutions & $\begin{array}{l}\text { Entrenchment of fossil interests in institutions of knowledge } \\
\text { production, etc.: petro-universities and state-subsidized R\&D }\end{array}$ \\
\hline Nub-national & $\begin{array}{l}\text { Alberta as petro-state, fossil boosterism in extractive and } \\
\text { sacrifice zones }\end{array}$ \\
\hline Transnational & $\begin{array}{l}\text { Contention around the 'national interest', through elite policy- } \\
\text { planning and online extractivist populist networks }\end{array}$ \\
\hline $\begin{array}{l}\text { Global governance and transnational policy-planning to } \\
\text { manage crisis and maintain fossil-capital predominance }\end{array}$ \\
\hline
\end{tabular}

In everyday life, Matthew Huber (2013) has explored how the hegemony of fossil capital was cemented in post-war America, with the rise of suburbanized consumerism. Within this assemblage, the individual experiences automobility as empowering and liberating, and the single detached house as a domain of personal sovereignty. The long-range result, in social formations organized around suburbanized consumer capitalism, has been to constrain politics within narrow limits 'focused on the family, private property, and anticollectivist sentiments' (Huber 2013, 79) the stock-and-trade of neoliberalism. Deeply ingrained in everyday pleasures and conveniences is the hegemony of fossil capital. 
Emily Eaton and Simon Enoch's (2020) ethnographic research shows how fossil corporations have instilled a 'hegemonic community economic identity' in small-town Saskatchewan as citizens embrace the frames and narratives of the petroleum industry. In these instances, a fossil-capitalist world view is deeply lodged in identity and community, as the allocative power of corporations to fund local amenities combines with the discursive power of industry-propagated frames. Communities come to see their fate and industry's fate as inextricably linked and they rise to the defense of companies against threats posed by climate-activist 'outsiders'.

In Canada, some local communities are Indigenous, and their strong claims to land and self-governance have always troubled a hegemonic bloc based in settler colonialism. Genocidal policies succeeded for many decades in marginalizing and silencing Indigenous voices, but have bequeathed a legacy of injustice that in our era demands reparation. Resurgent Indigenous politics speaks in an ethico-political voice, defending Mother Earth and championing buen vivir with an appealing alternative vision. Yet as Clifford Atleo (2020) argues, Indigenous struggles for selfdetermination coexist, ambivalently, with capitalism's powerful capacities to invade 'every corner of the earth and our imaginations.' Settler capitalism was founded on accumulation by dispossession (Coulthard 2014), and as Indigenous peoples' land was stolen many lost their livelihoods and migrated to cities, where land-based sensibilities may weaken. This has led some, including some Indigenous leaders, to internalize the logic of neoliberal capitalism within a contradictory consciousness between the aspiration for Indigenous resurgence and the lure of securing a portion of the wealth that capital and state are intent on continuing to extract from Indigenous lands. Within advanced settler colonialism, one version of self-determination now envisages Indigenous peoples as sovereign participants in a capitalist way of life, garnering the benefits of resource extraction within 'a despiritualized world understood simply as a business opportunity' (Coburn and Atleo 2016: 190). This accumulation strategy is favoured by the Canadian state and capitalist class, as a means of winning effectively permanent consent to capitalist development on Indigenous land. The struggle for hearts and minds is no less salient for Indigenous peoples than for non-Indigenous.

At subnational scale, we encounter a diversity of scenarios, shaped by the uneven spatial distribution of carbon resources. In extractive and sacrifice zones, fossil boosterism tends to prevail, with good-news narratives displacing dissent and critique. As Laurie Adkin (2016) holds, Alberta in particular functions largely as a petro-state. At first blush, British Columbia, immediately to the west of Alberta and currently governed by a social-democratic/green alliance that opposes the expansion of a bitumen pipeline from Alberta to Vancouver, might appear as just the opposite. Yet the ongoing capitalization of massive reserves of methane in BC's northeast suggests otherwise, as does the 'captured' status of the BC Oil and Gas Commission, which rubberstamps new fossil-capital projects (Daub, Ejeckam, Graham and Yunker, 2020). In Alberta, where fossil capital reigns supreme, the same regulatory capture is evident, but hegemonic reach extends to an industrial-scientific complex which subsidizes corporate profitability by lowering production 
costs as it also transfuses market values into the public sphere (Carroll, Graham and Yunker 2018). Fossil capital's reach into this domain exemplifies hegemonic practices within specific institutions. In 'Petro-universities and the production of knowledge for the post-carbon future' Laurie Adkin (2020) documents how fossil-capital interests have become entrenched, both within state innovation agencies that fund university-based research and within Alberta's universities themselves.

At national scale, the struggle for hearts and minds is condensed into contention around the 'national interest'. Here we can discern a shift from the hard-denialism of Harper to a Trudeau regime that acknowledges fossil capital's central role in the climate crisis while denying the need to decarbonize energy systems at a pace commensurate with what we know from climate science. As a hegemonic intervention, this 'new denialism' (Daub, Blue, Rajewicz and Yunker 2020) advocates technological and market-based fixes that buy time for continuing to ramp-up carbon extraction while creating new profit-making opportunities, both for fossil capital and for a subordinate but growing renewables sector. The strategic gambit is to win a measure of popular support while neutralizing opposition. The Trudeau government's 2016 announcement of a PanCanadian Framework on Clean Growth and Climate Change, nine days after approving two major pipeline projects (one of which the federal government now owns), is exemplary (Linnitt 2016). This seemingly incoherent construction of the national interest continues a long tradition of brokerage politics for which the Liberal Party of Canada has been the leading agent. The 'national interest' in 'clean growth' addresses the interests of Alberta-centred fossil capital and eastern-based finance and manufacturing while promising jobs to workers and a healthy environment. But with TMX now stalled and a right-wing populist government in Ontario, the Framework has been unraveling. The challenges facing the Framework illustrate how entrenched fossil capital interests are within the federated Canadian polity, and how low-tax, light-regulation neoliberalism deepens those trenches.

Of course, the practices that maintain a wider historical bloc for fossil capitalism extend beyond the state-capital nexus (Apeldoorn, De Graaff and Overbeek 2017), in both elite and popular registers. Board interlocks enable carbon-sector reach into knowledge-producing domains of civil society, in an elite network that is centred in Alberta yet linked to the centralCanadian corporate elite through hegemonic capitalist organizations that include business councils, think tanks and industry associations. The many threads of communication and collaboration in civil society afforded by interlocking governance boards enable the fossil-capital elite to advance its profit-driven concerns as in the national interest, 'obstructing the kinds of changes that could decarbonize our ecological footprint in a timely manner, but that also threaten corporate profits and control of economic decisions' (Carroll, Graham, Lang, McCartney and Yunker 2018: 446).

Elite networks are complemented by what Gunster et al. (2020) term emergent online networks of extractivist populism in combination constituting a petrobloc 'oriented around neoliberal extractivism, ecoskepticism and transnational "market fundamentalist" epistemic communities' (Neubauer 2017: iii). The populist wing portrays 'ordinary people' as victims of 
liberal elites who impose their values upon everyone else (Gunster and Saurette 2014). Rapid growth of extractivist groups on social media, sometimes directly sponsored by fossil capital, marks a strategic shift from traditional advertising towards targeted mobilization to convert passive stakeholders into engaged issue publics. In constructing a pro-fossil 'national interest' based partly in anti-elite resentment, these groups combine conventional pro-business tropes (e.g., jobs vs environment, opposition to state regulation) with more innovative discourses to construct accessible, appealing and easily shared legitimating narratives and frames. Online extractivist communities become 'echo chambers' that insulate industry supporters from the wider world, accentuating the public sphere's fragmentation and impeding public conversations crucial to democracy (Ferguson 2018).

Elite networks have also been important in maintaining an historical bloc at transnational scale. Space does not allow in-depth discussion of this complex issue. My own research (Carroll 2019) shows that the segment of the global corporate elite network centred upon fossil capital is divided between a large, integrated community of mainly American corporations, a smaller Franco-German-Canadian configuration and a third, loosely-knit, diverse community in which British capital predominates. Fossil capital continues to occupy a central position in the American corporate community, as it does in Canada. The mapping also reveals a weaker presence of fossil capital on the European continent, an incipient alignment of European and Chinese capital (both financial and industrial), and the continuing marginality in the global corporate elite of Southernbased fossil capital (with the partial exception of China).

\section{Climate Capitalism?}

Still, changes are afoot, with China and Europe (and sub-nationally, states such as California) opening space for renewables in the energy mix while major financial institutions divest from the dirtiest fossil fuels, including Alberta's Tar Sands (McSheffrey 2017). ${ }^{6}$ This brings us to climate capitalism, an emergent accumulation strategy which 'seeks to redirect investments from fossil energy to renewable energy generation so as to foster an ecological modernization of production and reduce greenhouse gas (GHG) emissions' (Sapinski 2015: 268; Adkin 2017). The promise of climate capitalism is to shepherd the world to a safe landing without disrupting its essential nucleus in capitalist relations of production.

Intergovernmentally, the path to Climate Capitalism begins with the 1997 Kyoto accord, and runs, two decades on, through Paris. It is a rocky road. The world's putative hegemon never signed on to Kyoto and more recently announced its withdrawal from Paris. Yet Climate Capitalism has also gained traction, for example, among institutional investors. In 2018 Larry Fink, CEO of Blackrock, the world's leading asset manager, issued an open letter to fellow CEOs which

\footnotetext{
${ }^{6}$ BankTrack's ongoing compilation lists 16 major financial institutions that have ended financing for Tar Sands operations. See https://www.banktrack.org/campaign/banks that ended direct finance for tar sands, accessed 23 July 2019.
} 
struck a strong blow for proactive management of environmental impact. ${ }^{7}$ As Marx (1967b) observed, financial institutions are the 'general managers' of the total social capital. Such admonitions signal an awareness among those general managers of the threat climate change poses. Yet actions speak louder than words. According to an NGO-sponsored online campaign, Blackrock has 'a big problem': 'as the world's biggest investor, Blackrock is also the world's biggest owner of fossil fuel companies.'

Climate Capitalism is a strategy still under construction, promoted within elite networks that bring corporate leaders together with policy communities and other organic intellectuals. As Sapinski has shown, environmental policy groups interlock extensively with the world's largest corporations, constituting a 'climate capitalist corporate-policy elite' small in size but positioned at the heart of the global network (2015:273), with European firms most involved (Sapinksi 2016: 97). However, the presence of major fossil-capital companies at the heart of the network suggests 'a weak project of climate capitalism' (Sapinski 2015:276) - a slow transition to ecologically modernized production, averting stranded assets while allowing fossil capital to expand control of replacement energy sources (Sapinski 2016: 106). Indeed, as Tadzio Müller (2013) notes, in the German context, 'the short-term goal of the energy companies and their government allies is to delay the transition just long enough so that the companies can gain a good foothold in the renewables sector that allows them to be as dominant in the new energy system as they were in the old....'

Such 'transition capture' may figure in German accumulation strategies, but in Canada Graham's research points to 'a carbon extractive sector without plans for energy transition or transition capture' (2019:25). Big capital in Canada seems fully committed to the Tar Sands, as shown in the massive acquisition of previously foreign-controlled assets in 2017 (Jaremko 2017), repeated in May 2018 by the federal government, with its purchase of the full depreciated, existing Trans Mountain Pipeline. At the same time, the federal government, aided by aligned civil-society groups such as Smart Prosperity, trumpets an energy transition acceptable to fossil capital.

The Trudeau government's climate action plan can only be grasped as another instance of brokerage politics, melding fossil capitalism with climate capitalism: a robust 'sell-out' of bitumen (Bush 2018), while global demand still exists, combined with a gentle program of state support for renewables and other mitigation efforts. But time is not on this venture's side, as the costs of renewables already undercut carbon. A recent study (Mercure et al. 2018) charts the likely outcome. As demand for carbon wanes, stranding the fixed capital of high-cost producers, Canada's GDP is projected to plummet (in step with a milder US decline), while Europe and China grow as new centres of climate capitalism.

More generally, however, climate capitalism faces two big challenges: 1 / its pace of change is too slow, compared to the realities of the climate emergency and 2/ capital's growth imperative practically precludes a shrinking footprint. Geoengineering, through carbon capture and storage

\footnotetext{
${ }^{7}$ https://www.blackrock.com/corporate/investor-relations/2018-larry-fink-ceo-letter

${ }^{8}$ See (https://www.blackrocksbigproblem.com/.
} 
(CCS) or stratospheric aerosol injection (SAI), is in development, but CCS is unproven at utility scale and SAI has been deemed potentially dangerous on at global scale. Still, SAI is quickly moving from the margins (as a last-resort 'Plan B') to the mainstream. Rex Tillerson has described climate change as an "engineering problem" with "engineering solutions." As the climate crisis deepens, it is increasingly likely that SAI will be applied, at least to buy time for a managed transition in which capital's economic nucleus is fully protected. The danger is that capital's rapacious need to expand will require increasing doses of SAI as atmospheric carbon concentration climbs toward 500 ppm - with possibly catastrophic consequences. ${ }^{10}$

Climate capitalism fits the Gramscian notion of passive revolution quite well. ${ }^{11}$ Deployed in an organic crisis, when bourgeois hegemony has weakened, passive revolution is 'a strategy which allows the bourgeoisie to reorganize its dominance politically and economically' (Sassoon 1982: 134). Climate capitalism's system-friendly reforms are a formula for continuity in change, managed from above. They appeal to subjectivities already normalized within fossil-fueled consumer capitalism. Climate Capitalism's technocratic approach articulates with a 'depoliticization' tendency in mainstream environmentalism (Swyngedouw 2013). Implicitly, Climate Capitalism mobilizes fear, particularly fear of change. As Adam Pzreworski showed in his classic rational-choice account of hegemony as class compromise, workers at any given time 'face a choice between climbing upward toward the best situation they could obtain under capitalism and a temporary deterioration of their conditions on the road to socialism' (1985: 177). Moving beyond capitalism may be preferable in the long term, but the foreseeable immediate disruptions of transformative change are daunting to many.

Within Climate-Capitalism rhetoric, Justin Trudeau's mantra, to 'grow the middle class', invokes the reassuringly familiar desire for more of the same (material goods and services), while 'clean growth' provides the means to that regnant end. Efforts are underway to coopt and develop the cadres and organizations needed in constructing a Climate-Capitalism historical bloc whether in state-led climate leadership initiatives or in new state- and industry-supported groups in civil society, such as University of Ottawa-based Smart Prosperity (McCartney 2018).

In the struggle for hegemony, Climate Capitalism

\footnotetext{
9 Associated Press, “Climate change fears overblown, says ExxonMobil boss," The Guardian, 28 June 2012 , www.guardian.co.uk/environment/2012/jun/28/exxonmobil-climate-change-rex-tillerson

10 'As with all SRM technologies that only address global surface temperatures, dramatic perturbations in the climate system can be expected if SAI is deployed. Early research into SAI from the UK's Met Office Hadley Centre found that SAI could lead to severe drought in the Sahel region of Africa. While researchers found that this could possibly be countered by injecting particles into the southern hemisphere stratosphere instead, this would likely cause a failure of the rains in northeast Brazil.' http://www.geoengineeringmonitor.org/2018/06/stratospheric aerosol injection/ 11 June 2018

${ }^{11}$ As Surprise (2018: 1230) suggests, SAI is 'a mechanism that can relieve (for capital) some of the immediate pressures of the climate crisis and enable a passive revolution from fossil capitalism to green capitalism, blunting the more radical alternatives advanced by the climate justice movement.' See also Mookerjea (2017).
} 
- $\quad$ offers a system-affirming response to the climate crisis which tugs at consumerist hearts and technocratic minds, averts the need for any leap into unknown territory, and seems to carry minimal costs;

- $\quad$ promises to reconfigure the forces of production to avert runaway climate change, yet protects the relations of production which form the nucleus of a now-global, classdominated way of life; and

- $\quad$ portends a molecular shift in the historical bloc, as fossil capital enters managed decline while renewable energy substitutes (and associated workforces) develop under the control of big capital.

Yet even in the short term, success is doubtful. Climate capitalism, particularly through geoengineering, may effect a temporal fix to the climate crisis, but looming economic crisis is another matter. In the aftermath of the 2008 financial meltdown, only a tiny proportion of fictitious capital was written down; hence financial over-accumulation was not significantly mitigated. Global crisis management since then has combined renewed austerity with ultra-low interest rates, in a pattern of 'continual postponement, with low profitability, low growth and high levels of surplus capital seeking adventurous paths and creating new bubbles' (Potts 2011: 465). MorganChase's top analyst, Marko Kolanovic, sees the longest bull market in history crashing in a financial meltdown within a year or two, 'likely to result in social tensions similar to those witnessed 50 years ago in 1968' (Son 2018). As in 2008-9, a deep financial crisis layered onto the existing civilizational and ecological crisis will reshape the terrain on which the struggle for hearts and minds is fought, presenting both left and right with new opportunities and threats.

As several Gramscian scholars have suggested, to counter a passive revolution one must conduct an anti-passive revolution: a war of position which extends popular-democratic and class struggles 'so as to mobilize ever-wider sections of the population for democratic reforms' (Simon, 1982: 49; Buci-Glucksmann, 1979; Sassoon 1982). In that spirit, I want to turn to an alternative, currently on the margins of public discourse but not without the prospect of securing practical grounding in the emerging era.

\section{Energy democracy as non-reformist reform}

Energy democracy neatly condenses the double power shift, from fossil-fuel power to renewables and from corporate oligarchy to democratic control of economic decisions that is so urgently needed. A feasible and just alternative to the oligarchic organization of fossil capitalism and Climate Capitalism, energy democracy has been endorsed by the international trade union movement, including Canada's largest unions and the Canadian Labour Congress, through Trade Unions for Energy Democracy. Energy democracy's three overarching goals -- 'resisting the fossilfuel-dominant energy agenda while reclaiming and democratically restructuring energy regimes' (Burke and Stephens 2017: 35) - inform a strategy that connects the dots between divestment 
initiatives, First Nations protectors, anti-fracking protests, community solar projects, etc. (ibid: 45). As Sweeney and Treat conclude in their review of this emerging field,

a Just Transition is possible, but it will have to be demanded and driven forward by a broad, democratic movement, with unions playing a key role. There will be no Just Transition without social and political transformation, and such a transformation will be contingent on a successful challenge of existing ownership relations and the expansion of economic democracy at all levels. And there will be no such transformation until unions and their allies fully grasp the fact that such a transformation is both possible and absolutely necessary (2018: 43).

The three projects might be hypothetically charted as in Table 2, with Fossil Capitalism morphing in the organic crisis into Climate Capitalism while an incipient bloc organized behind Energy Democracy forms as an alternative.

Table 2: Fossil Capitalism Climate Capitalism and Energy Democracy

\begin{tabular}{|l:l|l|}
\hline Fossil Capitalism & Climate Capitalism & Energy Democracy \\
\hline organic crisis $\rightarrow$ & passive revolution & alternative strategy/project \\
\hline
\end{tabular}

There is evidence that such a bloc is emerging. Leading NGOs have recently formed an international Energy Democracy alliance and have created an open space for participating groups, at http://www.energy-democracy.net, where these core principles are presented:

- Universal access and social justice (ending energy poverty while reducing energy consumption and prioritizing needs of communities, households and marginalized people);

- $\quad$ Renewable, sustainable and local energy (shifting to renewables by leaving fossil fuels in the ground, divesting from fossil fuels and investing public funds in local renewable energy systems to create thriving communities);

- $\quad$ Public and social ownership (bringing energy production under democratic control, within new forms of public ownership by municipalities, citizens' collectives and workers);

- Fair play and creation of green jobs (building renewable energy through fairly paid, unionized jobs);

- Democratic control and participation (empowering citizens and workers to participate in energy policy by democratizing governance and instituting complete transparency).

We can recognize in this framing a project that is both ethico-political and economic/ecological, that addresses both forces and relations of production, and that resonates with the concerns of several intersecting movements. 
As Hall (1988) observed, the struggle for an alternative hegemony occurs on terrain already shaped by the existing hegemony. In this light we can revisit some of the key instances in fossilcapital hegemony, with an eye toward the forms that energy democracy might take at different scales.

Table 3: Practices of Fossil Capitalism and Energy Democracy at Different Scales

\begin{tabular}{|c|c|c|}
\hline Scale & Instances of fossil-capital hegemony & Practices of energy democracy \\
\hline Everyday life & $\begin{array}{l}\text { Fossil-fueled consumer capitalism as a } \\
\text { way of life, automobility as freedom }\end{array}$ & $\begin{array}{l}\text { Politically-inflected lifestyle } \\
\text { changes; informal local and online } \\
\text { discussion }\end{array}$ \\
\hline $\begin{array}{l}\text { Local } \\
\text { community }\end{array}$ & $\begin{array}{l}\text { Civic privatism/boosterism; } \\
\text { Indigenous ambivalence }\end{array}$ & $\begin{array}{l}\text { Free public transit, principled } \\
\text { alliance politics of decolonization } \\
\text { and democratization, subsidiarity }\end{array}$ \\
\hline Institutions & $\begin{array}{l}\text { Entrenchment of fossil interests in } \\
\text { institutions of knowledge production, } \\
\text { etc. }\end{array}$ & $\begin{array}{l}\text { Reclaiming public institutions, } \\
\text { divestment, science and technology } \\
\text { for the people }\end{array}$ \\
\hline Sub-national & $\begin{array}{l}\text { Fossil boosterism in extractive and } \\
\text { sacrifice zones }\end{array}$ & Reclaim Alberta, Iron and Earth \\
\hline National & $\begin{array}{l}\text { Contention over the 'national } \\
\text { interest', through elite policy-planning } \\
\text { and online extractivist populist } \\
\text { networks }\end{array}$ & $\begin{array}{l}\text { Leap, RAVEN (Respecting } \\
\text { Aboriginal Values and } \\
\text { Environmental Needs), Green New } \\
\text { Deal }\end{array}$ \\
\hline Transnational & $\begin{array}{l}\text { Global governance and transnational } \\
\text { policy-planning }\end{array}$ & $\begin{array}{l}\text { Trade Unions for Energy } \\
\text { Democracy, Indigenous } \\
\text { Environmental Network }\end{array}$ \\
\hline
\end{tabular}

In everyday life, politically-inflected lifestyle changes and informal networks that reject fossil-fueled consumerism can foster changes in 'common sense' that pull people away from the doxa of fossil-fueled consumerism and enlarge the popular base for energy democracy. Within local communities, decarbonization and decommodification of public transit can have a broader impact, as can practices such as community gardening that open alternatives to carboniferous industrial agriculture. Indigenous resistance to colonization, closely associated with Indigenous resurgence (Coburn and Atleo 2016), propels Aboriginal communities into positions of leadership, in alliance with environmental and other movements, in a principled politics of decolonization and democratization that reaches beyond local communities. Corporatized institutions such as universities can be reclaimed as public services, as can science and technology. At sub-national scale, grassroots groups like Reclaim Alberta are calling for a just transition that heals the Earth from fossil capital's notorious externalities, while Iron and Earth, led by tar sands workers, has 
created 'a platform to engage in renewable energy development issues, and to empower us to advocate for an energy future we can be proud of creating. ${ }^{\prime 2}$ Across Canada, Leap, both the Manifesto and the movement it has spawned, is a significant intervention in re-defining the national interest, which explicitly uses an energy democracy frame. RAVEN, an Indigenous-led initiative, provides material support in legal struggles over the integrity of traditional lands and cultures. ${ }^{13}$ As I write this essay, an important initiative has been taking shape, involving community-based discussions that feed into a bottom-up process to define 'what a Green New Deal should look like, to identify commonalities, and to start developing specific proposals. ${ }^{\text {'4 }}$ These struggles contest the notion of a "national interest" that prioritizes short-term economic gain from finite and polluting resources' (Berman 2018). Transnationally, hegemonic global governance is countered by networks from below that include the Indigenous Environmental Network and Trade Unions for Energy Democracy. ${ }^{15}$ Such formations are crucial since, in view of its scale and scope, fossil capitalism's organic crisis 'cannot be sensibly addressed without global vision and strategy' (Carroll 2016: 207).

The challenge is to articulate these progressive forces into a coherent bloc that includes energy-sector workers, for whom a just transition must foster 'upward-leveling relationships' so that as fossil energy is decommissioned displaced workers find comparable positions in a rapidly expanding renewable energy sector (Abramsky 2010: 657). Such formation requires dialogical engagement through communicative democracy, to undo the exclusionary practices that relegate some voices to the margins and that replicate, within the left, the logic of hierarchy (Carroll 2015: 666). Yet to encompass a deep transformation the bloc must extend beyond energy democracy per se. In view of the foundational relationship in Canada between colonialism and capitalism, decarbonization and democratization must be conjoined with decolonization, enhancing capacities for Indigenous self-determination. By the same token, the close symbiosis between energy and finance means that a robust energy democracy must bring the financial sector itself under democratic control. Much the same can be said about the need to undo hegemonic corporate power within communications media, to 'remake media' by democratizing public communication (Hackett and Carroll 2006).

For André Gorz (1967), non-reformist reforms are steps toward system change, which avoid co-optation by disturbing the capitalist status quo in ways that build popular power. Energy democracy is in this sense a bundle of targeted, non-reformist reforms, an 'entry project' (Brie 2010) that can open space for democratization and decolonization of economic, political and cultural life. In such a transformation, corporate power would give way to popular power and participatory planning in production and allocation, to environmental stewardship and authentic reconciliation, to a revitalized public sphere and inclusive community development. To address

\footnotetext{
12 See http://www.reclaimalberta.ca/, http://www.ironandearth.org/about us.

13 See https://leapmanifesto.org/en/the-leap-manifesto/, https://raventrust.com/.

14 See See https://act.greennewdealcanada.ca/what-we-heard/, where themes from over 150 town hall meetings held across Canada in the spring of 2019 are summarized.

15 See http://www.ienearth.org/, http://unionsforenergydemocracy.org/.
} 
the modalities of corporate power that sustain capitalist hegemony, energy democracy needs to develop in concert with other non-reformist reforms in the workplace, in finance and in cultural production, in a war of position that adds up to a project of democratic eco-socialism (cf. Baer 2019; Candieas 2013; Löwy 2018; Satgar 2018), incorporating, within an expansive historical bloc, those struggling for economic, climate and gender justice and against racism and ongoing colonization.

The case of Canada is helpful in illuminating substantive and strategic issues that resonate more widely throughout the Global North and, arguably, the world. The urgent struggle for a world beyond fossil capital may be the leading edge of convergent movements to create a socially just and ecologically vibrant world beyond capital.

\section{References}

Abramsky, Kolya. 2010. 'Sparking an energy revolution: building new relations of production, exchange and livelihood.' Pp. 628-657 in Kolya Abramsky (ed.), Sparking a Worldwide Energy Revolution: Social Struggles in the Transition to a Post-Petrol World. Oakland, CA: AK Press.

Apeldoorn, Bastiaan, Nana de Graaff and Henk Overbeek (eds.) 2017. The State-Capital Nexus in the Global Crisis. London: Routledge.

Adkin, Laurie E. (ed.). 2016. First World Petro-Politics: The Political Ecology and Governance of Alberta. Toronto: University of Toronto Press.

Adkin, Laurie. 2020. 'Petro-universities and the production of knowledge for the post-carbon future.' In William K. Carroll (ed.), Regime of Obstruction: How Corporate Power Blocks Energy Democracy. Edmonton: Athabasca University Press, in press.

Aglietta, Michel. 1979. A Theory of Capitalist Regulation. London: Verso.

Atleo, Clifford. 2020. 'Between a rock and a hard place: Canada's carbon economy and Indigenous ambivalence.' In William K. Carroll (ed.), Regime of Obstruction: How Corporate Power Blocks Energy Democracy. Edmonton: Athabasca University Press, in press.

Baer, Hans A. 2019. Democratic Eco-Socialism as a Real Utopia. New York: Berghahn Books.

Barbalet, J.M. 1985. 'Power and resistance.' British Journal of Sociology 36, pp. 531-548. 
Berman, Tzeporah. 2018. 'Why the Trans Mountain fight is over more than just a pipeline.' Opencanada.org 4 October https://www.opencanada.org/features/why-trans-mountainfight-over-more-just-pipeline/

Bieler, Andreas and Adam David Morton. 2018. Global Capitalism, Global War, Global Crisis. Cambridge: Cambridge University Press.

Brie, Michael. 2010. Entry Projects to a Politics of Solidarity. Berlin: Rosa Luxemburg Foundation. https://www.rosalux.eu/topics/global-power-and-resistance/entry-projects-to-a-politicsof-solidarity/

Buci-Glucksmann, Christine. 1979. 'State, transition, and passive revolution.' Pp. 207-36 in Chantal Mouffe (ed.), Gramsci and Marxist Theory. Boston: Routledge \& Kegan Paul.

Burke, Matthew J. and Jennie C. Stephens. 2017. 'Energy democracy: Goals and policy instruments for sociotechnical transitions.' Energy Research \& Social Science 33:35-48.

Bush, Martin. 2018. 'Is the TMEX pipeline a future stranded asset?' Climate Zone 8 June https://climatezone.org/2018/06/is-the-tmex-pipeline-a-future-stranded-asset/

Candeias, Mario. 2013. Green Transformation: Competing Strategic Projects. Berlin: Rosa Luxemburg Foundation. <rosalux-nyc.org/green-transformation $>$.

Carroll, William K. 2003. 'Undoing the end of history: Canada-centred reflections on the challenge of globalization.' Pp. 33-55 in Yildiz Atasoy and William K. Carroll (eds.), Global Shaping and its Alternatives. Aurora, Ontario: Garamond Press.

Carroll, William K. 2010. The Making of a Transnational Capitalist Class. London: Zed Books.

Carroll, William K. 2015. 'Robust Radicalism.' Review of Radical Political Economics 47: 663-8.

Carroll, William K. 2016. Expose, Oppose, Propose: Alternative Policy Groups and the Struggle for Global Justice. London and Halifax: Zed Books and Fernwood Publishing.

Carroll, William K. 2017. 'Canada's carbon-capital elite: a tangled web of corporate power.' Canadian Journal of Sociology 42:225-60.

Carroll, William K. 2018. 'Rethinking the transnational capitalist class.' Alternate Routes 29: 188206. 
Carroll, William K. 2019. 'Fossil capital, imperialism and the global corporate elite.' In Vishwas Satgar (ed.), US New Imperialism and the BRICS. Johannesburg: WITS University Press, in press.

Carroll, William K. and Shannon Daub. 2018. 'Corporate power, fossil capital, climate crisis: Introducing the Corporate Mapping Project.' Studies in Political Economy 99(2):111-13.

Carroll, William K., Nicolas Graham, Michael Lang, Kevin McCartney and Zoe Yunker. 2018. 'The corporate elite and the architecture of climate change denial: a network analysis of carbon capital's reach into civil society.' Canadian Review of Sociology 55:425-50.

Carroll, William K., Nicolas Graham and Zoe Yunker. 2018. 'Carbon capital and corporate influence: Mapping elite networks of corporations, universities and research institutes.’ Pp. 58-74 in Jamie Brownlee, Chris Hurl and Kevin Walby (eds.), Corporatizing Canada. Toronto: Between the Lines

Carroll, William K. and Jouke Huijzer. 2018. Who Owns Canada's Fossil-Fuel Sector? Mapping the network of ownership \& control. Vancouver: Canadian Centre for Policy Alternatives, available at: https://www.corporatemapping.ca/who-owns/

Carroll, William K. and Murray Shaw. 2001. 'Consolidating a neoliberal policy bloc in Canada, 1976 to 1996.' Canadian Public Policy 27:195-217.

Carroll, William K. and J.P. Sapinski. 2018. Organizing the 1\%: How Corporate Power Works. Halifax: Fernwood Publishing.

Coburn, Elaine and Clifford Atleo. 2016. 'Not just another social movement: Indigenous resistance and resurgence.' Pp. 176-194 in William K. Carroll and Kanchan Sakar (eds.), A World to Win. Winnipeg: ARP Books.

Coulthard, Glen. 2014. Red Skin, White Masks. Mineapolis: University of Minnesota Press.

Cox, Robert. 1987. Production, Power and World Order. New York: Columbia University Press

Crosby, Andrew and Jeffrey Monaghan. 2018. Policing Indigenous Movements. Halifax: Fernwood Publishing. 
Daub, Shannon, Gwendolyn Blue, Lise Rajewicz and Zoë Yunker. 2020. 'Episodes in the new climate denialism.' In William K. Carroll (ed.), Regime of Obstruction: How Corporate Power Blocks Energy Democracy. Edmonton: Athabasca University Press, in press.

Daub, Shannon, Chuka Ejeckam, Nicolas Graham and Zoë Yunker. 2020. 'Doing things better together': Industry capture of climate policy in BC.' In William K. Carroll (ed.), Regime of Obstruction: How Corporate Power Blocks Energy Democracy. Edmonton: Athabasca University Press, in press.

Durand, Cédric. 2017. Fictitious Capital. London: Verso.

Eaton, Emily and Simon Enoch. 2020. “The oil industry is us”: hegemonic community economic identity in Saskatchewan's oil patch.' In William K. Carroll (ed.), Regime of Obstruction: How Corporate Power Blocks Energy Democracy. Edmonton: Athabasca University Press, in press.

Ferguson, Niall. 2018. 'Social networks are creating a global crisis of democracy,' Globe and Mail 19 January https://www.theglobeandmail.com/opinion/niall-ferguson-social-networksand-the-global-crisis-of-democracy/article37665172/

George, Susan. 1997. 'How to win the war of ideas: Lessons from the Gramscian right.' Dissent, Summer, 47-53.

Gorz, André. 1967. Strategy for Labor: A Radical Proposal. Boston: Beacon Press..

Graham, Nicolas. 2019 'Canadian fossil capitalism, corporate strategy and post-carbon futures.' Canadian Review of Sociology.

Gramsci, Antonio. 1971. Selections from the Prison Notebooks. New York: International Publishers.

Gramsci, Antonio. 2007. Prison Notebooks, volume. 3. New York: Columbia University Press.

Gunster, Shane, Bob Neubauer, John Bermingham and Alicia Massie. 2020. “Our Oil”: Extractive populism in Canadian social media.' In William K. Carroll (ed.), Regime of Obstruction: How Corporate Power Blocks Energy Democracy. Edmonton: Athabasca University Press, in press.

Gunster, Shane and Saurette, Paul. 2014. 'Storylines in the Sands: News, Narrative and Ideology in the Calgary Herald.' Canadian Journal of Communication 39.3 (December): 333-359. 
Hackett, Robert A. and Philippa R. Adams. 2018. Jobs versus Environment? Labour's Voice in Corporate and Alternative Media Coverage of Canadian Pipeline Controversies. Vancouver: Canadian Centre for Policy Alternatives, available at: https://www.corporatemapping.ca/jobs-vs-environment/.

Hackett, Robert A. and William K. Carroll. 2006. Remaking Media: The Struggle to Democratize Public Communication. London: Routledge

Hall, Stuart. 1988. The Hard Road to Renewal: Thatcherism and the Crisis of the Left. London: Verso

Huber, Martin. 2013. Lifeblood. Minneapolis: University of Minnesota Press.

Hughes, David J. 2018. Canada's Energy Outlook: Current Realities and Implications for a CarbonConstrained Future. Vancouver and Edmonton: Canadian Centre for Policy Alternatives and Parkland Institute. https://energyoutlook.ca/

Jaremko, Deborah. 2017. 'Charts: Canadian Companies about to Own 80 Percent of Oilsands Production.' JWN (March 30). Accessed 18 June 2018. http://www.jwnenergy.com/ article/2017/3/charts-canadian-companies-about-own-80-percent-oilsands-production/.

Jessop, Bob. 1983. 'Accumulation strategies, state forms, and hegemonic projects.' Kapitalistate 13: 89-111.

Jessop, Bob. 2002. The Future of the Capitalist State. Cambridge: Polity Press.

Klein, Naomi. 2014. This Changes Everything. New York : Simon \& Schuster.

Leys, Colin. 2001. Market-driven Politics. London: Verso.

Linnitt, Carol. 2016. 'Trudeau approves Kinder Morgan Trans Mountain Pipeline as part of Canada's "Climate Plan". The Narwhal 29 November https://thenarwhal.ca/trudeauapproves-kinder-morgan-trans-mountain-pipeline-part-canada-s-climate-plan/

Löwy, Michael. 2018. 'Why ecosocialism: for a red-green future.' Great Transition Initiative, December https://www.greattransition.org/publication/why-ecosocialism-red-greenfuture. 
McCartney, Kevin. 2018. Pricing Air to Starve the Fire: An Institutional Ethnography of Smart Prosperity. Master's thesis, University of Victoria.

McCarthy, Shawn. 2017, 'National Energy Board needs major overhaul, panel says.' Toronto Globe and Mail May 15, https://beta.theglobeandmail.com/report-on-business/industrynews/energy-and-resources/dismantle-neb-create-bodies-for-regulation-growthpanel/article34989230/?ref=http://www.theglobeandmail.com .

McSheffrey, Elizabeth. 2017. 'France's biggest bank shuns oilsands.' National Observer October 13 https://www.nationalobserver.com/2017/10/13/news/frances-biggest-bank-shunsoilsands

Malm, Andreas. 2016. Fossil Capital. London: Verso Books.

Marx, Karl. 1967a. Capital volume 2. New York: International Publishers.

Marx, Karl. 1967b. Capital volume 3. New York: International Publishers.

Mercure, J.-F., H. Pollitt, J. E. Viñuales, N. R. Edwards, P. B. Holden, U. Chewpreecha, P. Salas , I. Sognnaes, A. Lam and F. Knobloch. 2018. 'Macroeconomic impact of stranded fossil fuel assets.' Nature Climate Change 8: 588-593.

Meyer, Carl. 2018. 'Too many investors still see climate action as anti-profit, says Quebec pension fund boss.' National Observer 18 September https://www.nationalobserver.com/2018/09/18/news/too-many-investors-still-seeclimate-action-anti-profit-says-quebec-pension-fund

Mitchell, Timothy. 2011. Carbon Democracy. Verso Books.

Mookerjea, Sourayan. 2017. 'Petrocultures in passive revolution: the autonomous domain of treaty politics.' Pp. 325-354 in Sheena Wilson, Adam Carlson and Imre Szeman (eds.), Petrocultures. Montreal and Kingston: McGill-Queens University Press.

Müller, Tadzio. 2013. 'Of energy struggles, energy transitions and energy democracy.' Luxemburg April, https://www.zeitschrift-luxemburg.de/of-energy-struggles-energy-transitions-andenergy-democracyl/

Nikiforuk, Andrew. 2010. Tar Sands. Vancouver: Greystone Books. 
Potts, N. 2011. 'Marx and the crisis.' Capital \& Class 35: 455-473.

Neubauer, Robert. 2017. Gateway to Crisis: Discourse Coalitions, Extractivist Politics, and the Northern Gateway Conflict. Doctoral dissertation, Simon Fraser University.

Przeworski, Adam. 1985. Capitalism and Social Democracy. New York: Cambridge University Press.

Rabson, Mia. 2018. 'No G20 member has climate plan strong enough to meet Paris targets: report.' National Observer 15 November https://www.nationalobserver.com/2018/11/15/news/nog20-member-has-climate-plan-strong-enough-meet-paris-targets-report.

Rowley, Elizabeth. 2017. 'Bill C-59: Another threat to democracy', People's Voice 29 June, http://peoplesvoice.ca/2017/06/29/bill-c-59-another-threat-to-democracy/, accessed 2 August 2018.

Sapinski, JP. 2015. 'Climate capitalism and the global corporate elite network.' Environmental Sociology 1:4, 268-279.

Sapinski, JP. 2016. 'Constructing climate capitalism: corporate power and the global climate policy-planning network.' Global Networks 16: 89-111.

Satgar, Vishwas. 2018. 'The climate crisis and systemic alternatives.' Pp. 1-27 in Vishwas Satgar (ed.), The Climate Crisis. Johannesburg: WITs University Press.

Sweeney, Sean and John Treat. 2018. Trade Unions and Just Transition: The Search for a Transformative Politics. Trade Unions for Energy Democracy. April, http://unionsforenergydemocracy.org/wp-content/uploads/2018/04/TUED-WorkingPaper-11.pdf.

Sassoon, Anne S. 1982. 'Hegemony, war of position and political intervention.' Pp. 94-115 in Anne S. Sassoon (ed.), Approaches to Gramsci. London: Writers and Readers Publishing Cooperative Society Ltd.

Simon, Roger. 1982. Gramsci's Political Thought. London: Lawrence and Wishart

Sol, Hugh. 2018. 'JP Morgan's top quant warns next crisis to have flash crashes and social unrest not seen in 50 years.' CNBC 4 September https://www.cnbc.com/2018/09/04/jpmorgansays-next-crisis-will-feature-flash-crashes-and-social-unrest.html 
Sum, Ngai-Ling and Bob Jessop. 2013. Towards a Cultural Political Economy. Northampton, MA: Elgar.

Surprise, Kevin. 2018. 'Preempting the Second Contradiction: Solar Geoengineering as Spatiotemporal Fix.' Annals of the American Association of Geographers, 108:5, 1228-1244, DOI: $10.1080 / 24694452.2018 .1426435$

Swyngedouw, E. (2013). 'Apocalypse now! Fear and doomsday pleasures.' Capitalism Nature Socialism, 24(1), 9-18.

Urry, John. 1981. The Anatomy of Capitalist Societies. New York: Macmillan.

Vacca, G. 1982. 'Intellectuals and the Marxist Theory of the State,' in Approaches to Gramsci, ed. A. Showstack Sassoon. London: Writers and Readers, pp. 37-69.

Van der Pijl, Kees and Y. Yurchenko. 2014. 'Neoliberal Entrenchment of North Atlantic Capital: From Corporate Self-Regulation to State Capture.' New Political Economy 20(4): 1-23.

Wainwright, Joel and Geoff Mann. 2018. Climate Leviathan. London: Verso. 